\title{
Effect of a moderate feed restriction on subsequent growth and body composition in pigs raised under high environmental temperatures*
}

\author{
A. Daza ${ }^{1}$, A. Olivares ${ }^{2}$ and C. López-Bote ${ }^{2,3}$ \\ IDepartamento de Producción Animal. ETSI Agrónomos, \\ Universidad Politécnica de Madrid \\ 28040 Madrid, Spain \\ ${ }^{2}$ Facultad de Veterinaria. Universidad Complutense \\ 28040 Madrid, Spain
}

(Received 7 November 2005; revised version 20 June 2006; accepted 5 July 2006)

\begin{abstract}
The experiment was conducted to assess the influence of a moderate feed restriction during the growth period on overall performance, corporal traits and fatty acid composition in pig backfat in pigs raised under high environmetal temperatures. A hundred Large White $\mathrm{x}$ (Large White $\mathrm{x}$ Landrace) barrows with an average initial weight of $34.5 \mathrm{~kg}$ were randomly distributed, in pens (10 pigs per pen). Fifty pigs were fed ad libitum for 36 days (AL pigs) and another fifty were restricted by $25 \%$ of their ad libitum consumption during the same period (R pigs). During the subsequent re-feeding period (64 days) all pigs were fed ad libitum. The only diet used contained 13.4 MJ ME $\mathrm{kg}^{-1}, 17 \%$ crude protein and $1.3 \%$ lysine. The minimum, maximum and mean average temperatures recorded during the feed restriction and post-restriction periods were, ${ }^{\circ} \mathrm{C}: 21.5 \pm 1.2,28.6 \pm 1.3$ and $25.0 \pm 1.1$, and $22.6 \pm 0.9,31.2 \pm 1.0$ and $26.9 \pm 0.9$, respectively. Considering the whole study period, the average daily gain and average daily feed intake were higher $(\mathrm{P}<0.05)$ for AL pigs than for R pigs ( $840 \mathrm{vs} 808 \mathrm{~g}$ and $2478 \mathrm{vs} 2383 \mathrm{~g}$ ), although the feed conversion ratio was not different $(\mathrm{P}>0.05)$ (2.95 vs $\left.2.95 \mathrm{~kg} \mathrm{~kg}^{-1}\right)$. At the end of experiment, no differences for dorsal fat thickness and area and for longissimus dorsi muscle depth, width and area, measured at site of the last rib by means of a real-time ultrasound device, were found between experimental groups. The linolenic acid proportions of the subcutaneous fat outer and inner layer were higher in AL than in R pigs $(\mathrm{P}<0.05)$, while palmitic and saturated fatty acids total proportions of the subcutaneous fat inner layer were higher in $\mathrm{R}$ than in AL pigs $(\mathrm{P}<0.05)$.
\end{abstract}

KEY WORDS: compensatory growth, corporal traits, fatty acids profile, climate

\footnotetext{
* Supported by MEC-CICYT, AGL2004-06958GAN

3 Corresponding author: e-mail: clemente@vet.ucm.es
} 


\section{INTRODUCTION}

Although there is a general agreement on the positive effect of compensatory growth during the post-restrictive period in pigs (Lovatto et al., 2000), there is a lack of consistency in the literature regarding the overall effect on growth and feed intake considering together the restrictive and the post-restrictive periods. Thus, Wiesemüller et al. (1978) observed an improvement of overall average daily gain as well as feed conversion ratio while Campbell et al. (1983), Prince et al. (1983) and Donker et al. (1986) found an improvement only in overall feed conversion ratio and not in average daily gain when feeding level was restricted during grower phase. Critser et al. (1995) and Daza et al. (2003) found no improvement either in overall daily gain or in feed efficiency, despite the compensatory growth during the finishing period.

Lack of homogeneity between different experiments may be due to differences in pig age and length and intensity of the restriction period (Critser et al., 1995). Moreover, the differences observed among experiments are probably related to differences in intake capacity and growth potential of the pigs used and to environmental conditions (Donker et al., 1986; Chiba et al., 1999; Daza et al., 2003).

Carcass and meat quality characteristics may also be affected by compensatory growth. In some experiments compensatory growth produced pigs with leaner carcass (Campbell et al., 1983; Donker et al., 1986). However, other studies observed no difference in carcass traits at slaughter between restricted pigs and pigs with ad libitum access to feed during growth period (Prince et al., 1983; Valaja et al., 1992; Critser et al., 1995; Daza et al., 2003). On other hand, the possible influence of compensatory growth on backfat fatty acid composition of selected pigs has been hardly studied, although fatty acid metabolism is largely affected by feed intake and metabolic regulation.

Therefore, further research is justified in this area, since feeding strongly influences the final cost per kilogram at slaughter. The present experiment was conducted to asses the effect of a moderate feed restriction during the growth period on performance, body composition and fatty acid patterns of backfat in selected pigs.

\section{MATERIAL AND METHODS}

\section{Experimental design and diet}

A hundred castrated male Large White $\times$ (Large White $\times$ Landrace) pigs with an average weight of $34.5 \mathrm{~kg}(\mathrm{SEM}=0.52)$ were used. The experiment involved two treatments. Feed was provided either ad libitum (AL) or restricted by $25 \%$ of 
the ad libitum consumption (R) for the first 36 days of the experiment, followed by ad libitum feeding for the second part of the experiment (64 days) in all groups. Each treatment was replicate five times (10 pigs per replicate). All replicates were randomly distributed in an experimental housing facility. The initial weight of the animals by treatment and replicate was homogenized as much as possible. Each replicate was provided with a manger and a linear $(0.3 \mathrm{~m} / \mathrm{pig})$ feed box, as well as a water supply. Thirty percent of the floor was taken up by slats. The available area per pig during the experiment was $1.1 \mathrm{~m}^{2}$. The housing facility was ventilated by air extractors and has not any system of temperature control.

Pigs were fed a commercial diet whose chemical composition and ingredients are shown in Tables 1 and 2. Analysis of the diet was carried out according to AOAC (1995).

Table 1. Ingredients and chemical composition of experimental diet

\begin{tabular}{|c|c|c|c|}
\hline Ingredients & $\mathrm{g} / \mathrm{kg}^{-1}$ & Composition & $\mathrm{g} / \mathrm{kg}^{-1}$ \\
\hline Maize & 50.5 & Dry matter & 894.9 \\
\hline Soft wheat & 226.1 & Crude fat & 50.1 \\
\hline Barley & 410.2 & Crude protein & 169.8 \\
\hline Lucerne & 22.8 & Lysine $^{2}$ & 9.1 \\
\hline Soyabean meal (47) & 230.1 & Gross energy, MJ. kg-1 & 17.6 \\
\hline Lard & 28.5 & Metabolizable energy, MJ. $\mathrm{kg}^{-1} 2$ & 13.4 \\
\hline Calcium carbonate & 5.9 & & \\
\hline Dicalcium phosphate & 12.1 & & \\
\hline Sodium chloride & 4.0 & & \\
\hline L-lysine & 4.9 & & \\
\hline Premix $^{1}$ & 5.0 & & \\
\hline \multicolumn{4}{|c|}{$\begin{array}{l}{ }^{1} \text { per kg of premix: vit. } \mathrm{A}, 1500000 \mathrm{IU} ; \text { vit. } \mathrm{D}_{3}, 420000 \text {; ppm: vit. E } 2000 ; \text { vit. } \mathrm{B}_{2}, 800 ; \text { vit. } \mathrm{B}_{6} \\
\text { 100; vit. } \mathrm{K}, 150 \text {; vit. } \mathrm{B}_{12}, 4000 \text {; d-pantotenic acid, 1600; nicotinic acid, 2970; biotine, } 10 \text { ppm } \\
\text { choline, } 36500 \text {; vit. C, } 990 ; \mathrm{Se}, 40 ; \mathrm{I}, 150 ; \mathrm{Co}, 220 ; \mathrm{Cu}, 5000 ; \mathrm{Fe}, 7500 ; \mathrm{Zn}, 23400 ; \mathrm{Mn}, 7500 \\
\text { calculated }\end{array}$} \\
\hline \multicolumn{4}{|c|}{ Table 2. Fatty acid composition of experimental diet } \\
\hline Fatty acid & & $\mathrm{g} / \mathrm{kg}^{-1}$ diet & \\
\hline C16:0 & & 11.3 & \\
\hline C16:1(n-7) & & 0.7 & \\
\hline C18:0 & & 4.6 & \\
\hline C18:1(n-9) & & 14.0 & \\
\hline C18:2(n-6) & & 16.8 & \\
\hline C18:3(n-3) & & 1.4 & \\
\hline C20:1(n-9) & & 0.4 & \\
\hline
\end{tabular}




\section{Data collection}

Data were recorded of individual pig weight and feed consumption per replicate on days 0 (initial day of experiment), 36 (end of the restriction period) and 100 (end of the experiment). On days 36 and 100 on all pigs measurements were obtained by means of a real-time ultrasound apparatus RTU (Kretz Technick INC-600 V232, Sonovet, Austria). Images were freeze and saved and then lineal and area measurements were taken by mean of the software provided by the device. Three operators carried out all measurements independently and the final value for each variable was considered the mean of the three. The following ultrasonic measurements were taken at the level of the last rib:

BF1 - fat thickness in mm measured at the medial edge of the longissimus dorsi muscle from the skin to the muscle

$\mathrm{BF} 2$ - fat thickness in $\mathrm{mm}$ measured at $6 \mathrm{~cm}$ from the dorsal mid line from the skin to the longissimus dorsi muscle

BF3 - fat thickness in mm measured from the lateral edge of longissimus dorsi from the skin to the muscle

BFA - fat area in $\mathrm{mm}^{2}$ limited by the longissimus dorsi (superior face), the skin (internal face) and the measurement described in BF1 and BF3

LDD - longissimus dorsi muscle depth in mm

LDW - M. longissimus dorsi width in $\mathrm{mm}$

LDA - M. longissimus dorsi area in $\mathrm{mm}^{2}$.

Backfat biopsy samples were taken at the end of the restrictive period (36 days). In addition, a backfat sample was taken following the same procedure in pigs immediately after slaughter. Biopsy samples were taken at $6 \mathrm{~cm}$ beside the backbone at the level of the lumbar zone using a metal cylinder (diameter 0.25 $\mathrm{cm}$ ) with a sharpened edge. All necessary precautions were taken to prevent animal discomfort during and after the in vivo sampling processes. This included tranquillization with $40 \mathrm{mg}$ of azaperon (Stressnill, Labopica, Madrid) $1 \mathrm{~h}$ before biopsy and local anaesthesia with $2 \%$ lidocaine-HCL, immediately prior to sample collection. Afterwards, animals received a $2 \mathrm{ml}$ penicillin intramuscular injection (300000 IU /ml, Labopica, Madrid).

Lipids from subcutaneous fat were extracted by procedure proposed by Bligh and Dyer (1959). Fat extracts were methylated in the presence of sulphuric acid and analysed by gas chromatography as described elsewhere (Rey and LopezBote, 2001) using a 6890 Hewlett Packard gas chromatograph and a $30 \mathrm{~m} \times 0.32$ $\mathrm{mm} \times 0.25 \mu \mathrm{m}$ cross-linked polyethylene glycol capillary column.

Environmental temperature in experimental housing facility was daily monitored using a maximum-minimum thermometer. 


\section{Statistical analysis}

The data were analysed as a completely randomised design using the general linear model (GLM) procedure contained in SAS version 8 (SAS, 1999). The main variable was the treatment ( $\mathrm{Al}$ vs R), but included the initial weight of the pigs as the covariate for weight and average daily gain, and the weight of the replicates as the covariate for feed consumption and feed conversion ratio. Data corresponding to ultrasound measurements and fatty acid composition of subcutaneous outer and inner fat layers were treated by means of analysis of variance. Student test was used to compare fatty acid composition between outer and inner layers. The interaction of treatment with time was studied by repeated measures analysis. Statistical significance was set at $\mathrm{P}<0.05$.

\section{RESULTS AND DISCUSSION}

The minimum, maximum and mean average temperatures recorded during the feed restriction and post-restriction periods were, ${ }^{\circ} \mathrm{C}: 21.5 \pm 1.2,28.6 \pm 1.3$ and $25.0 \pm 1.1$, and $22.6 \pm 0.9,31.2 \pm 1.0$ and $26.9 \pm 0.9$, respectively.

The effect of treatment on weight and growth performance is presented in Tables 3 and 4, respectively. The R pigs, which consumed $75.3 \%$ the amount consumed by $\mathrm{AL}$ pigs during the restriction period had a lower $(\mathrm{P}<0.001)$ average daily gain (ADG) than the AL pigs, although no differences were found for feed conversion ratio (FCR) during this phase. These results agree

Table 3. Effect of feeding regime on change in pig weight ${ }^{1}$

\begin{tabular}{lccc}
\hline \multirow{2}{*}{ Feeding regime } & \multicolumn{3}{c}{ Weight, $\mathrm{kg}$} \\
\cline { 2 - 4 } & $0 \mathrm{~d}$ & $36 \mathrm{~d}$ & $100 \mathrm{~d}$ \\
\hline AL (50) & 34.6 & $65.8^{\mathrm{a}}$ & $118.5^{\mathrm{a}}$ \\
$\mathrm{R}(50)$ & 34.3 & $58.8^{\mathrm{b}}$ & $115.3^{\mathrm{b}}$ \\
SEM & 0.52 & 0.74 & 0.83 \\
\hline
\end{tabular}

${ }^{1}$ least square means. $\mathrm{AL}=$ ad libitum, $\mathrm{R}=$ restricted, $\mathrm{SEM}=$ standard error of mean within column, means with different

${ }^{a, b}$ superscripts are different $\mathrm{P}<0.05$

Table 4. Effect of feeding regime (AL or R) on average daily gain (ADG), average daily feed intake (ADFI) and feed conversion rate $(\mathrm{FCR})^{1}$

\begin{tabular}{|c|c|c|c|c|c|c|c|c|c|}
\hline \multirow{2}{*}{$\begin{array}{l}\text { Period, } \\
\text { days }\end{array}$} & \multicolumn{2}{|c|}{ ADG, $g$} & \multirow{2}{*}{ SEM } & \multicolumn{2}{|c|}{ ADFI, $g$} & \multirow{2}{*}{ SEM } & \multicolumn{2}{|c|}{ FCR $\mathrm{kg} \cdot \mathrm{kg}^{-1}$} & \multirow{2}{*}{ SEM } \\
\hline & $\mathrm{AL}$ & $\mathrm{R}$ & & $\mathrm{AL}$ & $\mathrm{R}$ & & $\mathrm{AL}$ & $\mathrm{R}$ & \\
\hline $0-36$ & $870^{\mathrm{a}}$ & $676^{\mathrm{b}}$ & 14.6 & $1999^{\mathrm{a}}$ & $1505^{b}$ & 91.7 & 2.30 & 2.23 & 0.06 \\
\hline $37-100$ & $828^{a}$ & $877^{\mathrm{b}}$ & 9.4 & $2710^{\mathrm{a}}$ & $2914^{\mathrm{b}}$ & 27.7 & 3.27 & 3.32 & 0.06 \\
\hline $0-100$ & $840^{\mathrm{a}}$ & $808^{\mathrm{b}}$ & 6.6 & $2478^{\mathrm{a}}$ & $2383^{b}$ & 28.0 & 2.95 & 2.95 & 0.04 \\
\hline
\end{tabular}

${ }^{1}$ are least square means. $\mathrm{AL}=$ ad libitum, $\mathrm{R}=$ restricted, $\mathrm{SEM}=$ standard error of mean means within each row and experimental period, with different superscripts are different $\mathrm{P}<0.05$ 
with those of other authors (Campbell et al., 1983; Prince et al., 1983; Skiba et al., 2002; Daza et al., 2003). During the post-restrictive period (36-100 days), the R pigs showed a higher average daily feed intake $(\mathrm{ADFI})(\mathrm{P}<0.004)$ and $\mathrm{ADG}(\mathrm{P}<0.01)$ than the AL pigs, but no differences were found for FCR. The R pigs could not fully compensate during the post-restriction period for the growth reduction experienced during the restriction phase. Considering the whole study period (restriction and postrestriction phases) the AL pigs had higher final weight $(\mathrm{P}<0.016), \mathrm{ADG}(\mathrm{P}<0.016)$ and ADFI $(\mathrm{P}<0.032)$ than the $\mathrm{R}$ pigs while no difference $(\mathrm{P}<0.77)$ for $\mathrm{FCR}$ was observed. These results agree with those reported by Lovatto et al. (2000), but are in disagreement with those obtained by Campbell et al. (1983), Prince et al. (1983) and Donker et al. (1986). These authors observed that when feed restriction was moderate (15-30\% of the ad libitum consumption) compensation by $\mathrm{R}$ pigs during the ad libitum re-feeding phase (post-restriction period) was complete regarding growth and improved FCR for re-feeding and whole periods. Daza et al. (2003) also found a complete growth compensation and an improvement of FCR during post-restriction period when feed restriction was moderate, although no difference was observed for FCR during the whole period (growth and finishing phases).The incomplete compensation observed in the $\mathrm{R}$ pigs of our experiment may be explained by high temperatures recorded during post-restriction period which might have mitigate the higher feed consumption potential of $\mathrm{R}$ pigs compared to the $\mathrm{AL}$ pigs. In another experiment (Daza et al., 2003), in which feed restriction was also moderate ( $25 \%$ of the ad libitum consumption) and the pigs were in thermoneutral conditions during the post-restriction period the average daily feed intake difference between $\mathrm{R}$ and $\mathrm{AL}$ pigs was higher than that recorded in this experiment (286 vs $204 \mathrm{~g}$ ), and a complete compensation of weight was achieved. Moreover, the higher ADFI of R pigs during the post-restrictive period should have increased their maintenance heat production, due to a weight increase of active metabolic organs (Koong et al., 1985), as well as the expenses of heat corresponding at a greater feed intake and more active digestion and metabolism (Milgen et al., 2000). There are some previous reports indicating that temperature can modify overall growth in compensatory growth experiments (Donker et al., 1986; Chiba et al., 1999).

On other hand, according Whang et al. (2003) during the period of compensatory growth the requirement of crude protein for those pigs previously restricted is higher than that of pigs previously fed an adequate diet. Therefore, it may be that in our experiment the higher average daily protein intake of $\mathrm{R}$ pigs during re-feeding period had not been sufficient to compensate the growth reduction found during the restrictive phase.

The effect of feeding regime on ultrasound measurements values taken on live pigs is presented in Table 5. At the end of the restriction period, the lean and fat ultrasound measurements were higher in AL pigs than in R pigs. This result agrees 
Table 5. Effect of feeding regime (AL or R) on ultrasound estimation of longissimus dorsi muscle and backfat meassurements

\begin{tabular}{|c|c|c|c|c|c|c|}
\hline \multirow[b]{2}{*}{ Variable } & \multicolumn{3}{|c|}{ End of restriction period } & \multicolumn{3}{|c|}{ End of post-restriction period } \\
\hline & $\mathrm{AL}$ & $\mathrm{R}$ & SEM & $\mathrm{AL}$ & $\mathrm{R}$ & SEM \\
\hline LDD, mm & $35^{\mathrm{a}}$ & $30^{\mathrm{b}}$ & 0.9 & 51 & 52 & 1.0 \\
\hline LDW, mm & $64^{\mathrm{a}}$ & $59^{\mathrm{b}}$ & 1.1 & 88 & 86 & 0.9 \\
\hline $\mathrm{LDA}, \mathrm{mm}^{2}$ & $1552^{\mathrm{a}}$ & $1249^{b}$ & 50.6 & 3476 & 3485 & 69.5 \\
\hline $\mathrm{BF} 1, \mathrm{~mm}$ & 11 & 9 & 0.4 & 16 & 16 & 0.5 \\
\hline $\mathrm{BF} 2, \mathrm{~mm}$ & $10^{\mathrm{a}}$ & $7^{\mathrm{b}}$ & 0.3 & 17 & 16 & 0.6 \\
\hline $\mathrm{BF} 3, \mathrm{~mm}$ & 12 & 10 & 0.5 & 19 & 21 & 0.9 \\
\hline $\mathrm{BFA}, \mathrm{mm}^{2}$ & $800^{\mathrm{a}}$ & $553^{\mathrm{b}}$ & 37.4 & 1846 & 1887 & 69.4 \\
\hline LDA/BFA & 1.94 & 2.26 & 0.08 & 1.90 & 1.85 & 0.07 \\
\hline
\end{tabular}

$\mathrm{AL}=$ ad libitum; $\mathrm{R}=$ restricted; ${ }^{\mathrm{a}, \mathrm{b}}$ within each row and experimental period, with different superscripts are different $\mathrm{P}<0.05$

with that obtained by Skiba et al. (2002) but is in disagreement with that observed by Campbell et al. (1983), who did not find differences for carcass lean and fat between AL and R pigs at the end of the restriction phase. During the postrestriction phase the average daily gain rates of longissimus dorsi muscle lean and fat areas were higher in $\mathrm{R}$ than in $\mathrm{AL}$ pigs $(\mathrm{P}<0.05)$ (33.15 vs 30.82, $\mathrm{SE}=3.31$, and $19.68 \mathrm{vs} 17.56 \mathrm{~mm}^{2}, \mathrm{SE}=2.01$, respectively) although at the end of the re-feeding period no differences were found for lean and fat areas between AL and R pigs. These results are in agreement with those observed by Campbell et al. (1983), Prince et al. (1983), Valaja et al. (1991), Critser et al. (1995) and Daza et al. (2003), although Donker et al. (1986), using moderate feed restriction levels (15 and $28 \%$ of the ad libitum consumption), detected a higher carcass lean content in R than in AL pigs. The lack of any difference in lean and fat areas observed in our experiment at the end of the post-restriction period may be explained because greater differences in feed consumption between R and AL pigs would have had to occur during the ad libitum fattening phase or during the whole experimental period (Mersmann et al., 1989; Ramaekers et al., 1996).

The influence of feeding regime on fatty acid composition of subcutaneous fat outer and inner layers is shown in Table 6. At the end of the restriction phase a higher and lower proportion of $\mathrm{C} 16: 0$ and $\mathrm{C} 18: 0$, respectively were detected in subcutaneous fat outer layer from $\mathrm{AL}$ pigs $(\mathrm{P}<0.05)$, while no differences for C18:1(n-9), C18:2(n-6), C18:3(n-3), total saturated fatty acids ( $\sum$ SFA), total monounsaturated fatty acids ( $\sum$ MUFA) and total polyunsaturated fatty acids ( $\sum$ PUFA) proportions and unsaturated index (UI) between AL and R pigs were observed. However, in the subcutaneous fat inner layer no difference in C16:0 proportion was found between $\mathrm{AL}$ and $\mathrm{R}$ pigs, but a higher proportion of C18:0, C18:1(n-9), $\sum$ SFA and $\sum$ MUFA and a lower proportions of C18:2(n-6), $\mathrm{C} 18: 3(\mathrm{n}-3)$ and $\sum$ PUFA were observed in $\mathrm{R}$ pigs $(\mathrm{P}<0.05)$, which produced a 
Table 6. Influence of feeding regime on fatty acid profile of subcutaneous backfat outer (a) and inner (b) layers

\begin{tabular}{|c|c|c|c|c|c|c|}
\hline \multirow[t]{2}{*}{ Fatty acid } & \multicolumn{2}{|c|}{$\begin{array}{c}\text { End of restriction period } \\
\text { feeding regime }\end{array}$} & \multirow[t]{2}{*}{ SEM } & \multicolumn{2}{|c|}{$\begin{array}{c}\text { End of post-restriction period } \\
\text { feeding regime }\end{array}$} & \multirow[t]{2}{*}{ SEM } \\
\hline & ad libitum & restricted & & ad libitum & restricted & \\
\hline \multicolumn{7}{|l|}{ (a) } \\
\hline C16:0 & $21.85^{\mathrm{a}}$ & $20.81^{b}$ & 0.15 & 21.85 & 22.18 & 0.14 \\
\hline C18:0 & $9.66^{\mathrm{a}}$ & $10.35^{\mathrm{b}}$ & 0.12 & 11.13 & 10.80 & 0.19 \\
\hline C18:1 (n-9) & 37.29 & 37.52 & 0.26 & 39.12 & 38.49 & 0.21 \\
\hline C18:2 (n-6) & 19.59 & 19.64 & 0.28 & 16.90 & 17.47 & 0.32 \\
\hline C18:3 (n-3) & 1.60 & 1.49 & 0.032 & $1.04^{\mathrm{a}}$ & $0.96^{\mathrm{b}}$ & 0.021 \\
\hline$\sum \mathrm{SFA}$ & 33.32 & 33.00 & 0.20 & 34.99 & 35.04 & 0.27 \\
\hline$\sum$ MUFA & 44.29 & 44.41 & 0.29 & 45.44 & 45.22 & 0.36 \\
\hline$\sum$ PUFA & 22.39 & 22.59 & 0.33 & 19.57 & 19.75 & 0.35 \\
\hline$\sum n-6 / \sum n-3$ & 11.98 & 12.59 & 0.42 & $15.83^{\mathrm{a}}$ & $17.92^{\mathrm{b}}$ & 0.54 \\
\hline UI & 0.92 & 0.93 & 0.020 & 0.89 & 0.88 & 0.022 \\
\hline \multicolumn{7}{|l|}{ (b) } \\
\hline C16:0 & 22.17 & 22.12 & 0.15 & $22.84^{\mathrm{a}}$ & $23.68^{b}$ & 0.26 \\
\hline C18:0 & $11.82^{\mathrm{a}}$ & $13.21^{\mathrm{b}}$ & 0.23 & 14.08 & 14.29 & 0.28 \\
\hline C18:1 (n-9) & $34.16^{\mathrm{a}}$ & $36.01^{\mathrm{b}}$ & 0.25 & 38.11 & 37.37 & 0.25 \\
\hline C18:2 (n-6) & $21.15^{\mathrm{a}}$ & $18.20^{\mathrm{b}}$ & 0.24 & 15.28 & 15.02 & 0.27 \\
\hline $\mathrm{C} 18: 3(\mathrm{n}-3)$ & $1.80^{\mathrm{a}}$ & $1.25^{\mathrm{b}}$ & 0.05 & $0.88^{\mathrm{a}}$ & $0.75^{b}$ & 0.04 \\
\hline$\sum \mathrm{SFA}$ & $35.88^{\mathrm{a}}$ & $37.19^{b}$ & 0.17 & $38.87^{a}$ & $40.00^{\mathrm{b}}$ & 0.29 \\
\hline$\sum$ MUFA & $39.78^{a}$ & $41.96^{\mathrm{b}}$ & 0.11 & 43.59 & 43.02 & 0.24 \\
\hline$\sum$ PUFA & $24.34^{\mathrm{a}}$ & $20.85^{b}$ & 0.24 & 17.54 & 16.98 & 0.27 \\
\hline$\sum n-6 / \sum n-3$ & $11.63^{\mathrm{a}}$ & $14.37^{\mathrm{b}}$ & 0.63 & $17.02^{\mathrm{a}}$ & $19.09^{\mathrm{b}}$ & 0.64 \\
\hline UI & $0.93^{\mathrm{a}}$ & $0.87^{\mathrm{b}}$ & 0.005 & 0.82 & 0.80 & 0.007 \\
\hline
\end{tabular}

SEM = standard error of mean. C16:0, C18:0, C18:1 (n-9), C18:2 (n-6), C18:3 (n-3), $\sum$ SFA, $\sum$ MUFA, $\sum$ PUFA, $\sum$ n-6/ $\sum$ n-3 and UI = palmitic, stearic, oleic, linoleic, linolenic, total saturated (SFA), total monounsaturated (MUFA), total poly-unsaturated (PUFA) fatty acids, $\sum n-6 / \sum n-3$ ratio and unsaturated index (UI), respectively

within each row and experimental period, means with different superscripts are different $\mathrm{P}<0.05$

higher UI in AL pigs than in $\mathrm{R}$ pigs $(\mathrm{P}<0.05)$. However, in the outer layer the feeding level affected only the C16:0 proportion. Accordingly, the results of this experiment indicate that the feeding level reduction during restriction period led to a higher variation in fatty acid composition in the inner than in the outer backfat layer. Several experiments (López-Bote et al., 2002; Daza et al., 2005b) have also reported a more marked alteration in the inner than in the outer layer as a consequence of dietary manipulation. The subcutaneous backfat inner layer was more saturated than the outer layer in both AL and R pigs. Bee et al. (2002) observed higher fatty acid synthase (FAS) enzyme activity in the subcutaneous backfat inner layer than in the outer.

At the end of the post-restriction period a higher $\mathrm{C} 16: 0$ and $\sum$ SFA proportions in subcutaneous fat inner layer $(\mathrm{P}<0.05)$ and a lower $\mathrm{C} 18: 3(\mathrm{n}-3)$ proportion in both 
outer and inner layers were observed in $\mathrm{R}$ pigs $(\mathrm{P}<0.05)$, which may be due to the higher ADFI of R pigs regarding AL pigs during re-feeding phase. Kuhn and Burgstaller (1996) did not find differences in fatty acid composition of subcutaneous fat outer layer between AL and R pigs at slaughter $(155-165 \mathrm{~kg})$ that were fed concentrate diets $(13.0$ and $11.5 \mathrm{MJ} / \mathrm{kg}$ and $14-18$ and $12-16 \%$ crude protein, respectively) between 54 and $109 \mathrm{~kg}$ and fed high feeding level until slaughter.

In both AL and R pigs, it can be observed that $\sum$ SFA and $\sum$ MUFA increased, and $\sum$ PUFA decreased when pig weight increased. These results are in agreement with those reported by Pérez (2004).

At the end of the restriction and post-restriction periods the outer layer was more unsaturated than the inner both in $\mathrm{AL}$ and $\mathrm{R}$ pigs $(\mathrm{P}<0.05)$. It is interesting to note that $\mathrm{C} 18: 0$ seems to concentrate in the inner layer. These results are in agreement with those observed by López-Bote et al. (2002) and Daza et al. (2005a). Nevertheless, at the end of the restriction period the subcutaneous fat inner layer from AL pigs had a higher proportion of C18:2(n-6) and $\sum$ PUFA than those subcutaneous fat outer layer $(\mathrm{P}<0.05)$.

At the end of post-restriction period, the subcutaneous backfat outer and inner layers from $A L$ pigs had a lower $\sum \mathrm{n}-6 / \sum \mathrm{n}-3$ ratio $(\mathrm{P}<0.05)$ than $\mathrm{R}$ pigs, which is interesting from the nutritional point of view, since current dietary guidelines recommend decreasing this ratio (Wood and Enser, 1997).

In conclusion, moderate feed restriction during the growth period $(25 \%$ of the ad libitum intake) did not improve overall performances in this experiment, probably due to the high temperatures that occurred during the re-feeding period. The partial compensatory growth had a low effect on fatty acid profile of subcutaneous fat outer layer, although it increased the $\sum$ SFA proportion in subcutaneous fat inner layer.

\section{REFERENCES}

AOAC, 1995. Official Methods of Analysis, Association of Official Analytical Chemists. $16^{\text {th }}$ Edition. Arlington, VA

Bee G., Gebert S., Messikommer R., 2002. Effect of dietary energy supply and fat source on the fatty acid pattern of adipose and lean tissues and lipogenesis in the pig. J. Anim. Sci. 80, 1564-1574

Bligh E.G., Dyer W.J., 1959. A rapid method of total lipid extraction and purification. Can. J. Biochem. Physiol. 37, 911-917

Campbell R.G., Taverner M.R., Curic D.M., 1983. Effects of feeding level from 20 to $45 \mathrm{~kg}$ on the performance and carcass composition of pigs grown to $90 \mathrm{~kg}$ live weight. Livest. Prod. Sci. 10, 265-272

Chiba L.I., Ivey H.W., Cummins K.A., Gamble B.E., 1999. Growth performance and carcass traits of pigs subjected to marginal dietary restrictions during the grower phase. J. Anim. Sci. 77, 1769-1776

Critser D.J., Miller P.S., Lewis A.J., 1995. The effects of dietary protein concentration on compensatory growth in barrows and gilts. J. Anim. Sci. 73, 3376-3383 
Daza A., Mateos A., Rey A.I., López-Bote C.J., 2005b. Feeding level in the period previous to the late fattening phase influences fat composition at slaughter in free-range pigs. Arch. Anim. Nutr. 59, 227-236

Daza A., Rey A.I., Isabel B., López-Bote C.J., 2005a. Effect of dietary vitamin E and partial replacement of poly-with monounsaturated fat on fatty acid patterns of backfat and intramuscular fat in heavy pigs (Iberian x Duroc). J. Anim. Physiol. Anim. Nutr. 89, 20-28

Daza A., Rodríguez I., Ovejero I., López-Bote C.J., 2003. Effect on pig performance of feed restriction during the growth period. Span. J. Agr. Res. 1, 3-8

Donker R.A., Den Hartog L.A., Brascamp E.W., Merks J.W.M., Noordewier G.J., Buiting G.A.J., 1986. Restriction of feed intake to optimise the overall performance and composition of pigs. Livest. Prod. Sci. 15, 353-365

Koong L.J., Ferrell C.L., Nienaber J.A., 1985. Assessment of interrelationships among levels of intake and production, organ size and fasting heat production in growing animals. J. Nutr. 15, 1383-1389

Kuhn M., Burgstaller G., 1996. Energy and protein restriction during the compensatory growth in pigs (in Spanish). Rev. Suinicoltura 37, 49-51

Lopez-Bote C.J., Isabel B., Daza A., 2002. Partial replacement of poly-with monounsaturated fatty acids and vitamin E supplementation in pigs diets: effect on fatty acid composition of subcutaneous and intramuscular fat and on fat and lean firmness. Anim. Sci. 75, 349-358

Lovatto P.A., Suvant D., Milgen Van J., 2000. Study and modelization of compensatory growth in pigs (in Spanish). XXXII Journée Recherches Porcine (France) 32, 241-246

Mersmann H.J., Mac Neil M.D., Seideman S.C., Pond W.G., 1989. Compensatory growth in finishing pigs after feed restriction. Swine Research Progress Report. Roman L. Hruska. U.S. Meat Animal Research Centre 3, 34-36

Milgen Van J., Noblet J., Dubois S., 2000. Modellings of the constituents of the energy expense in pigs (in Spanish). XXXII Journée Recherches Porcine (France) 32, 235-24

Pérez M., 2004. Effect of gender, feeding program and slaughter weight on productivity and meat quality characteristics in Iberian Retinto x Duroc pigs (in Spanish). Department of Animal Production, School of Agronomy, Politechnics University, Madrid, pp. 225

Prince T.J., Jungst S.B., Kuhlers D.L., 1983. Compensatory responses to short-term feed restriction during the growing period in swine. J. Anim. Sci. 56, 846-852

Ramaekers P.J.L., Swinkels J.W.G.M., Huiskes J.H., Verstegen M.W.A., Hartog Den L.A., PeetSchwering Van Der C.M.C., 1996. Performance and carcass traits of individual pigs housed in groups as affected by ad libitum and restricted feeding. Livest. Prod. Sci. 47, 43-50

Rey A.I., Lopez-Bote C.J., 2001. Effect of dietary copper and vitamin E supplementation, and extensive feeding with acorns and grass on longissimus muscle composition and susceptibility to oxidation in Iberian pigs. J. Anim. Physiol. Anim. Nutr. 85, 281-292

SAS, 1999. Institute SAS /Stat User's Guide: SAS, Cary, NC

Skiba G., Fandrejewski H., Raj S., Weremko D., 2002. The influence of previous protein or energy restriction of young pigs on their daily gain composition. J. Anim. Feed Sci. 11, 299-308

Valaja J., Alaviuhkola T., Suomi K., Immonen I., 1992. Compensatory growth after feed restriction during the rearing period in pigs. Agr. Sci. Finland 1, 15-20

Whang K.Y., Kim S.W., Donovan S.M., McKeith F.K., Easter R.A., 2003. Effects of protein deprivation on subsequent growth performance, gain of body components, and protein requirements in growing pigs. J. Anim. Sci. 81, 705-716

Wiesemüller W., Otto E., Poppe S., Behm R., Hackl W., 1978. Studies regarding performancerelated lysine requirement of fattening pigs. 3. Influence of amino-acid and energy-intake on fat, protein and lysine deposition (in German). Arch. Anim. Nutr. 28, 305-316

Wood J.D., Enser M., 1997. Factors influencing fatty acids in meat and the role of antioxidant in improving meat quality. Brit. J. Nutr. 78, S49-S60 